\title{
Making Offenders Vote: Democratic Expressivism and Compulsory Criminal Voting
}

\author{
ANDREI POAMA Leiden University \\ TOM THEUNS Utrecht University
}

\begin{abstract}
$T s$ criminal disenfranchisement compatible with a democratic political order? This article considers this question in light of a recently developed view that criminal disenfranchisement is justified because it expresses our commitment to democratic values. We call this view expressive disenfranchisement and refer to the general conception in which it is grounded as democratic expressivism. Contra supporters of expressive disenfranchisement, we argue that democratic expressivism does not offer a sound justification of criminal disenfranchisement. Additionally, we argue that, insofar as one really cares about answering serious criminal wrongs via an expression of democratic values, criminal disenfranchisement should be abandoned and replaced with a policy that temporarily obliges the relevant criminals to vote. Democratic expressivists should, in other words, move from supporting the disenfranchisement of serious offenders to endorsing a policy of compulsory criminal voting for a finite period of time.
\end{abstract}

\section{INTRODUCTION}

$\mathbf{M}$ ost contemporary democracies authorize some form of criminal disenfranchisement. Criminal disenfranchisement refers to the legally sanctioned practice whereby some convicted criminal offenders-most frequently, felons-are deprived of their right to vote. Denial of the franchise is typically triggered by a prison sentence. Blais, Massicotte, and Yoshinaka (2004) show that only about $25 \%$ of the 63 democracies they analyze let all their prisoners vote. A sizable number of democracies thus disenfranchise at least some of their prisoners. More strikingly, offenders are sometimes stripped of their right to vote after their release from prison. ${ }^{1}$ In Europe, there are only nine countries that do not impose any restrictions on suffrage in or after prison, whereas in the US, 48 states and the District of Columbia restrict it during imprisonment and 31 states keep the restrictions for persons on probation (Tripkovic 2016).

Andrei Poama (iD), Assistant Professor, Faculty of Governance and Global Affairs, Leiden University, a.poama@fgga.leidenuniv.nl.

Tom Theuns (iD, Postdoctoral Researcher, Utrecht University; Research Associate, University College Roosevelt; and Associate Researcher, Centre for European Studies, and Comparative Politics, Sciences Po Paris, t.j.h.theuns@uu.nl.

The authors would like to thank the participants of the panel on The Politics and Ethics of Disenfranchisement held at the MANCEPT conference in Manchester in September 2017, the 'Philosophy and Public Affairs' seminar held at the University of Amsterdam in October 2017, the colloquium in practical philosophy held at Utrecht University in October 2018, and the seminar of the Center for Political Philosophy at the University of Leiden. Particular thanks are given to Bert van den Brink, Marcus Carlsen Häggrot, Carlo Invernizzi Accetti, Eva Groen-Reijman, Steven Klein, Annabelle Lever, Tom Parr, Diana Popescu, Milena Tripkovic, Alexandru Volacu, Fabio Wolkenstein, Toon Kerkhoff, Natascha van der Zwan, Alexandre Afonso, and Sarah Giest. Tom Theuns would like to acknowledge funding from the European Union's Horizon 2020 research and innovation program under grant agreement No. 727112 since February 2018.

Received: April 6, 2018; revised: October 23, 2018; accepted: April 5, 2019.

${ }^{1}$ This happens in Germany, see Tripkovic (2016).
These pervasive electoral exclusions should make us wonder why a political regime that is generally premised on the enfranchisement of its citizens should concur in depriving some of them of their right to vote. Do democracies ever have good democratic reasons to support criminal disenfranchisement? Put differently, is criminal disenfranchisement compatible with or required by a democratic political order?

In exploring these questions, we focus on a recently developed view which argues that, when rightly designed and enforced, criminal disenfranchisement is desirable as an expression of democratic values. We call this view expressive disenfranchisement and refer to the general conception in which it is grounded as democratic expressivism. Unlike various other justifications for criminal disenfranchisement, expressive disenfranchisement does not seem to rely on dubious empirical assumptions about the instrumental advantages of criminal disenfranchisement or to entertain morally abhorrent positions that dehumanize offenders. ${ }^{2}$

However, despite its apparent plausibility and putative promise to guide criminal justice and electoral reform, we argue that democratic expressivism does not offer a sound justification of any form of criminal disenfranchisement Additionally, insofar as one cares about answering serious criminal wrongs via an expression of democratic values, we argue that criminal disenfranchisement should be replaced

\footnotetext{
${ }^{2}$ Prominent instrumental arguments for criminal disenfranchisement can be broadly grouped into 'republican' and 'contractual' groups. 'Republican' strategies focus on the need to prevent the subversion of the vote by felons (Clegg 2001; Manfredi 1998), and have been shown by Sigler (2014,1731) and Reiman (2005,7-8) to rest on speculative (and empirically dubious) assumptions about felons, especially about felons construed as groups (López-Guerra 2014, 114). A similarly weak instrumental argument focuses on the deterrent function of disenfranchisement (ibid; Cholbi 2002, 557; Bennett 2016, 416). A different, 'contractual', approach holds that criminal acts undermine a social contract (Ewald 2002). As Lippke $(2001,561)$, has pointed out, this strategy also demands a public-goodbased justification of disenfranchisement, which runs into the same empirical worries as republican arguments. Further, Schall $(2006,78)$ and Beckman $(2009,125-6)$ note that convicted criminals continue to be subject to society's laws, and thus part of the social contract.
} 
with a policy that temporarily obliges felons to vote. Democratic expressivists should move from supporting disenfranchising offenders to endorsing a policy of compulsory criminal voting for a finite period of time.

Note that neither expressive disenfranchisement nor our compulsory voting view endorses the current actual practice of criminal disenfranchisement, which is often substantively indiscriminate in its application to all imprisonable crimes ${ }^{3}$ or, in certain jurisdictions, permanently imposed on some felons. ${ }^{4}$ On the expressive disenfranchisement view, existing cases where offenders are permanently disenfranchised or disenfranchised for democratically irrelevant reasons remain unjustified. But disenfranchisement for offenses carrying an antidemocratic message would continue to be justified, and thus partly uphold current practice on democratic grounds. On our view, no form of criminal disenfranchisement is justified. Note, furthermore, that we do not directly defend democratic expressivism. Although we think that it is a respectable position, we are attached only to the more modest claim that, granted that the franchise is an expression of democracy, obliging serious criminals to vote is preferable to disenfranchising them. This conditional qualifier is central to our critique of expressive disenfranchisement and to our electoral-cum-criminal policy proposal.

The article proceeds as follows. We begin with a characterization of democratic expressivism as applied to the franchise and a reconstruction of two formulations of expressive disenfranchisement. The first, which we call "declarative disenfranchisement," has been most notably developed by Andrew Altman (2005) and William Bülow (2016). It holds that disenfranchising some offenders is justified as a way of signaling that there are certain normative standards that members of the demos are committed to. The second, which we call "instructive disenfranchisement," has been most clearly articulated by Jean Hampton (1998) and Mary Sigler (2014). It argues that disenfranchising offenders is an appropriate medium for conveying the democratic values they have flouted. ${ }^{5}$ We then argue that, even under its most restrictive forms warranted by the declarative and instructive formulations of expressive disenfranchisement, criminal disenfranchisement is not justified. Additionally, we explain why democratic expressivism provides reasons for introducing a compulsory criminal voting policy. ${ }^{6}$ Finally, we offer a rough institutional outline for this policy.

\footnotetext{
${ }^{3}$ This is the case in the UK, where prisoners are indiscriminately deprived of their voting rights. In Hirst v. United Kingdom (2005), The European Court of Human Rights ruled that this blanket electoral is incompatible with art. 3, first Protocol of the ECHR.

${ }^{4}$ This happens in eleven US states. See: https://www.brennancenter. org/criminal-disenfranchisement-laws-across-united-states.

${ }^{5}$ We do not consider some expressivist views supporting criminal disenfranchisement, such as Manfredi (1998) or Ramsay (2013). Manfredi's argument ultimately depends on a republican rationale, and has been successfully criticized elsewhere (see fn 3). Whitt (2017) showed that Ramsay's argument rests on an inaccurate and normatively problematic premise, which is that political rights cannot be genuinely exercised in prison. The expressivist views we consider are immune to these critiques.

${ }^{6}$ This policy proposal contributes to the ongoing debate about compulsory voting in general and provides reasons for partial agreement between those who endorse compulsory voting (Lacroix 2007; Hill 2010; Hill in Brennan and Hill 2014, 111-204) and those who oppose it (Lever 2010; Saunders 2017, 2018).
}

\section{DEMOCRATIC EXPRESSIVISM AND EXPRESSIVE DISENFRANCHISEMENT}

Democratic expressivism holds that, no matter how you might otherwise justify them, some social and political institutions are warranted because they function as expressions of our commitment to democratic (or democratically relevant) values. Thus envisaged, some institutions are not only good for the kind of consequences they produce but also fit for what they say about our mode of relating to certain values. An example of democratic expressivism is Amy Gutmann's and Dennis Thompson's (2004) justification of political deliberation. They argue that, "on the expressive view of deliberation, significant value resides in the act of justifying laws and public policies to the people who are bound by them" (22), and that this value consists in conveying mutual respect for those engaged in that deliberative practice. Democratic expressivism is " $m o s t$ often proposed as a way of understanding the act of voting" (191-2). Thus applied, democratic expressivism holds that voting offers an adequate institutional medium whereby the demos can convey its commitment to democratic values, such as equality, inclusion, and participation.

Democratic expressivism about voting is a widely shared position. Elizabeth Anderson (2009) argues that voting and democratic participation are venues for "expressing mutual sympathy and respect for our fellow citizens" (225). Similarly, Adam Winkler (1993) points out that voting is primarily "a meaningful participatory activity through which individuals create and affirm their membership in the community" (331). Dennis Thompson (2004) underlines that "elections are not only instruments for choosing governments" but "also media for sending messages about the democratic process" (24). More recently, Emilee Chapman (2016) holds that democratic expressivism reflects folk conceptions of voting and democracy, according to which voting "instantiates and expresses the equality of all citizens" (244).

Expressive disenfranchisement should, we think, be understood as an attempt to draw on democratic expressivism to argue that serious criminal offenders should temporarily lose their franchise. Supporters of expressive disenfranchisement argue that serious crimes constitute expressions of contempt toward democratic values. To convey the demos' commitment to these values, the authors of these crimes ought to be temporarily disenfranchised. Expressive disenfranchisement thus relies on three basic premises. The first states that the franchise is an expressively justified democratic practice. Second, there are at least some crimes that convey a rejection of democratic (or democratically significant) values. Third, it is possible to design a form of criminal disenfranchisement that adequately expresses the democratic community's commitment to democratic values. In the rest of this section, we concentrate on how supporters of expressive disenfranchisement specify this third premise. In the following section, we argue that this premise is problematic and that, consequently, expressive disenfranchisement should be abandoned. 
There are two standing formulations of expressive disenfranchisement-namely, declarative and instructive disenfranchisement. These two formulations differ in their specification of the expressive function of criminal disenfranchisement. Understanding how disenfranchisement can be expressive requires that we clarify these two functions.

Declarative disenfranchisement has been most clearly articulated by Andrew Altman (2005) and William Bülow (2016). Altman (2005) contends that "a democratic citizenry has a collective right to (...) disenfranchise for the duration of their imprisonment felons who commit serious crimes" (271). This is to say that the principle of democratic self-determination renders disenfranchisement permissible. Altman goes on to argue that criminal disenfranchisement is also normatively desirable as an expression of the substantive normative commitments cherished by the demos. Disenfranchising serious offenders allows the state to declare its commitment to the "normative constraints" (269) violated by certain crimes. For Altman, a state that resorts to properly restricted criminal disenfranchisement is one that thereby "show(s) its respect for basic normative constraints on human behavior" (ibid.). This, Altman argues, is "an important part of the identity of their political community" (ibid.) and marks "an expression of respect" (ibid.) for the values involved in this identity.

Building upon Altman's argument, William Bülow (2016) holds that, because serious criminal offenders "have done something that is an appropriate concern not only for the victim but also for the political collective as a whole" (766) - namely, they have violated "rights that are fundamental to a free and democratic society" (ibid.)-democratic states that are committed to these rights may legitimately affirm their distance from such violations. The contention is that "it is possible to find identities and attitudes that a democratic collective may want to express but that cannot be expressed without felon disenfranchisement, for instance, 'we, as a democratic collective, hold that those who are considered full member (sic) in our community, and therefore may participate in shared democratic decision-making, should equally restrain from violating the sort of normative constraints that protect the rights and values which both underlie and are safeguarded by our democratic system"' (769). Thus construed, the motivation for disenfranchisement is to "express the standard of citizenship that defines the democratic collective in question" (771).

At its core, Altman's and Bülow's argument is that depriving felons of their right to vote is a felicitous venue for a demos to convey its attachment to those values that are called into question by serious crimes. In temporarily disenfranchising the authors of such crimes, the demos can be seen as declaring that, unlike the individual offender, it is not the kind of agent who violates fundamental rights to "life, freedom, and autonomy" (Bülow 2016, 763). The implication is that by tolerating individuals who reject basic democratic commitments - which, in this case, are specified as fundamental human rights - the state could be seen as not taking these commitments seriously enough.
Although they belong to the same philosophical family as Altman's and Bülow's arguments, some of the arguments advanced by Jean Hampton (1998) and Mary Sigler (2014) differ in their specification of the function of democratic expression. Like Altman and Bülow, Hampton and Sigler support the declaration of democratic commitments in the wake of criminal behavior, but they hold that disenfranchisement is additionally desirable because it can direct offenders toward an adequate mode of relating to democratic values. For Hampton, "expressing punitive responses such as the suspension of voting rights, have the potential for provoking thought that can bring about a change in the wrongdoer's way of thinking about himself and society" $(1998,43)$. For Sigler, "the suspension of voting rights is meant to heighten offenders' sense of civic responsibility by establishing the expectation of restored political participation" (2014, 1728). Sigler explicitly links this rationale to the dissenting opinion of Judge Gonthier in Sauvé v. Canada (2002), which argues that taking away the right to vote from serious offenders can provide a motivational mechanism for those offenders to understand what losing one's tie to those values means. ${ }^{7}$

Hampton and Sigler think that criminal disenfranchisement is an adequate policy for trying to persuade offenders that democratic values matters for them. Sigler argues that, suitably reformed, disenfranchisement can instruct offenders to acquire the "minimal civic virtue" and "shared commitment to a set of public values that constitute the political community" (2014, 1735). Similarly, Hampton construes criminal disenfranchisement in terms of moral education $(1998,40)$. Both Hampton and Sigler hold that the instructive message carried by disenfranchisement is informed by democratic values, in the sense that what is being (tentatively) taught is a certain understanding of democracy. Hampton takes the central democratic value to be political equality or the absence of "natural subordination" between individuals (1998, 29, 40). Sigler takes it to be the civic trust among democratic compatriots $(2014,1728)$.

Declarative and instructive disenfranchisement differ in how they specify their audiences. Declarative disenfranchisement is general, in that the expressive agent (the demos) also constitutes its audience. Instructive disenfranchisement is specific, in that the expressive agent (again, the demos) organizes its message so that it communicates with felons in a more direct and emphatic way. ${ }^{8}$ This difference is particularly salient in Hampton's discussion of what she calls the "specific" form of moral education, which is aimed at educating and communicating with the "criminal himself" (40), rather than addressing the general public, which the "general" form of moral education does.

\footnotetext{
7 Judge Gonthier quotes Hampton (1998) in Sauvév. Canada (2002), para. 72

${ }^{8}$ This distinction structurally corresponds to the one Wringe (2016, 42-65) makes between communicative penal expressivism, which is specifically aimed at offenders, and denunciatory penal expressivism, aimed at the political community at large.
} 
One might worry that instructive disenfranchisement is a faux expressivist view. Bringing instruction into the picture seems to take us from an expressive view of disenfranchisement to an instrumental view that defends disenfranchisement because it tends to transform felons' antidemocratic beliefs and behavior. If the instructive view were instrumentally grounded, it would seem invulnerable to our expressive objections, and should instead be evaluated on its instrumental efficacy. However, the instructive rationale advanced by Sigler and Hampton is structurally different from rehabilitationist, preventive or other instrumental views of criminal disenfranchisement. To be sure, rehabilitation and prevention remain normatively desirable. But the main argument Hampton and Sigler advance is that it is distinctly and intrinsically desirable to respond to antidemocratic behavior with democratic instruction. This is why Sigler insists that her instructive argument is "formal," which is to say that it would be defensible even if disenfranchisement did not succeed to secure the felons' democratic uptake (1737). ${ }^{9}$ It also explains why Hampton insists on separating her "educative communication" account from instrumentalist accounts like deterrence or rehabilitation (40-1). In short, what matters for Sigler and Hampton is that the state acts in an expressively adequate way when it pursues the felons' democratic instruction, even if that turns out to be instrumentally sub-optimal. ${ }^{10}$ This makes expressivism constitutive of (and thus necessary for) instructive disenfranchisement, and renders it vulnerable to the critiques we develop in the following section. ${ }^{11}$

\footnotetext{
${ }^{9}$ On this account, it is not a requirement of instructive expression to result in felons themselves consequently affirming the value. This does not render the task of indicating how instructive disenfranchisement generates good outcomes redundant. One can coherently defend a non-instrumental view (such as expressive instruction) that is properly constrained by, but is not instrumentally derived from, consequentialist considerations. The defensibility of this claim depends on the more general defensibility of so-called "restrictive" consequentialism, defended by Pettit and Brennan as the view arguing that "while it may be appropriate to evaluate options by the criterion of maximizing probable value, it need not be sensible to select them on that basis" $(1986,439)$.

${ }^{10}$ Alternatively, Sigler and Hampton might draw on Brennan and Lomasky (1993) to argue that democratic states have special expressive interests in presenting themselves as agents that respond to anti-democratic actions with democratically educational measures. In submitting felons to an instructive practice as a reaction to their crimes, democratic states expressively reveal that they care about democratic instruction even (or especially) when democratic values are flouted. ${ }^{11}$ Note that instructive expressivism does not imply that an instrumental account of instruction is off the table. Instructive expressivism only contends that no matter how otherwise it might be justified, criminal disenfranchisement can function as a democratically instructive expression, and this independently of any instrumental rationale one might attach to it. For this contention to be vindicated, it is sufficient to show that a non-instrumental account of democratic instruction and education is conceptually possible and normatively desirable in its own right, not that it offers a full-fledged conception of democratic instruction and education in general. For an expressively sensitive non-instrumental justification of education simpliciter (from which a non-instrumental justification of democratic education can be derived), see Peters ([1977] 2005, 63-72). For a discussion of how education into moral values can rest either on instrumental or on intrinsic grounds, see Carr (1991, 248-9).
}

If this characterization of instructive disenfranchisement is adequate, it will make sense to approach both declaration and instruction as expressive replies to attitudes conveyed by crimes which allegedly undermine democratic values. Summarizing, we have:

Declarative disenfranchisement: Criminal disenfranchisement is justified as a declarative expression of democratic values.

and

Instructive disenfranchisement: Criminal disenfranchisement is (further) justified as an instructive expression of democratic values.

A few additional remarks are in order. First, note that instructive disenfranchisement implies declarative disenfranchisement, but not vice versa. Given that disenfranchisement is defended as a public sanction, the belief that disenfranchising offenders instructs them about democracy can be held only if one also believes that criminal disenfranchisement works as a public declaration of democratic values. If the demos did not declare anything about its own commitment to democratic values via disenfranchisement, it would be hard to see how the same demos could try to instruct felons that those values are worth being committed to. Instruction stands or falls with declaration, and does so for expressivist reasons. ${ }^{12}$

Second, expressive disenfranchisement proposals are doubly limited. They are limited in time because they attempt to ground only provisional forms of disenfranchisement. Typically, expressive disenfranchisement is presented as coinciding with the length of prison terms. This is because felonies are usually punished with imprisonment, but neither of the authors we examine excludes disenfranchising noninmate felons during parole or probation if their offenses expressively violated democratic values.

Expressive disenfranchisement is also substantively limited to a small set of crimes that convey an antidemocratic message. What counts as an expressively antidemocratic crime will depend on one's underlying conception of democracy. For instance, one can argue that electoral fraud or threat to candidates will appear especially wrong on a participation-centered view of democracy, that treason and embezzlement or crimina falsi like perjury or forgery will be singled out by a trustbased conception of democracy, and that rape might be considered expressively antidemocratic on an equalitycentered account of democracy. ${ }^{13}$ Finally, neither

\footnotetext{
${ }^{12}$ We construe instruction as a communicative act and agree with Anderson and Pildes that communicative acts are "a subset of all expressive acts" $(2000,1565)$.

${ }^{13}$ Hampton thinks there is a politically inegalitarian aspect to rape that disenfranchisement could address by making the offender reflect on the value of equality. Allowing offenders who committed rape to vote is "like allowing the treasonous offender to vote: it hands political power to people who want to destroy the foundations of equality in our society. The message that such a policy conveys is not only insulting to those values, but also to the people who are the target of their hate" $(1998,41)$.
} 
version of expressive disenfranchisement incorporates instrumentalist concerns about the goals of voting in a democracy. On both accounts, criminal disenfranchisement is supposed to work as an expression of democratic values, not as a policy for maximizing generally desirable consequences (for instance, correct collective decisions) or, less ambitiously, for minimizing the probability of undesirable ones (say, social and political conflicts).

\section{TWO OBJECTIONS TO EXPRESSIVE DISENFRANCHISEMENT}

Democratic expressivism is prima facie plausible if one accepts the general desirability of democratic government. Other things equal, it seems justifiable for democratic communities to publicly commit themselves to democratic values. Also, one need not endorse a fully Rousseauian account of citizenship to recognize that democrats are not born but made, and that expressions of democratic values can have an important function in maintaining commitment to democratic government. We therefore endorse the democratic desideratum of expressing values such as equality (Hampton 1998), civic trust (Sigler 2014), or human rights (Altman 2005; Bülow 2016).

However, despite our favorable views about democratic expressivism, we believe that it cannot adequately support criminal disenfranchisement. This is for two main reasons. First, expressive disenfranchisement undermines the democratic values that are central to democratic expressivist accounts. ${ }^{14}$ Call this the performative contradiction objection. Second, and independently of our first objection, expressive disenfranchisement is vague when it comes to trying to persuade offenders that, in violating democratic values, they have lost something of value. Call this the vagueness objection. The scope of these two objections differs. The performative contradiction objection addresses the declarative account of expressive disenfranchisement and, by way of implication, applies to instructive disenfranchisement. The vagueness objection, in contrast, addresses only the instructive rationale for criminal disenfranchisement.

The two objections also differ in their strength. We argue that the performative contradiction objection is stronger, in that it offers sufficient grounds for discarding the two expressive rationales for criminal disenfranchisement. The vagueness critique is weaker, in that it remains hostage to the possibility of a plausible case being made about the pedagogical potential of criminal disenfranchisement. ${ }^{15}$ In the rest of this

\footnotetext{
${ }^{14}$ Our objections target the democratic values of equality (Hampton 1998), civic trust (Sigler 2014), and human rights (Altman 2005; Bülow 2016), but they would hold on other democratic values, such as inclusion or participation.

${ }^{15}$ This is not the same as offering empirical evidence about the pedagogical success of criminal disenfranchisement. Given the formal aspect of the instructive rationale, no such evidence would be required. Rather, what would be required is clarifying the logic of potential instructive mechanisms. We come back to this in the following section.
}

section, we flesh out the two objections. In the following section, we argue that replacing criminal disenfranchisement with compulsory criminal voting avoids these objections and adequately conveys the significance of democratic values.

\section{THE PERFORMATIVE CONTRADICTION OBJECTION}

Declarative disenfranchisement is open to a performative contradiction objection insofar as it undermines the values it purports to express. The core values identified in the different accounts vary. Hampton is worried that a criminal act can "hurt, brutalize, or damage the interests of another individual," in conflict with the democratic principle that "human beings have a worth that is high - and also the equal of every other person" $(1998,39)$. Sigler focuses on the "breach of civic trust that criminal wrongdoing represents" $(2014,1728)-$ a trust that "makes liberal democracy possible" (ibid.). Altman and Bülow state their concern in terms of human rights violations, and hold that "serious felonies violate... [the] basic human rights (...) of their victims" (Altman 2005, 269; Bülow 2016). Temporary criminal disenfranchisement is in each case tied to an expressive rationale. However, on reflection, such expressive rationales are inconsistent with the practice of criminal disenfranchisement. ${ }^{16}$

Strictly speaking, performative contradiction occurs when the content of a particular statement is in conflict with its utterance. Jaakko Hintikka considers a now classical example: "I do not exist" (Hintikka 1962, 32). In this case, performing the utterance disproves the content of the statement uttered. Our account is more complex, in that the performative (non)contradiction of a declarative expressivist justification for a particular act turns on the (non)contradiction of the act with the putatively expressed value. ${ }^{17}$ For instance, suppose one wants to expressively justify an act of civil disobedience.

\footnotetext{
${ }^{16}$ We are not the first to criticize the contradictory dimension of some of the arguments examined here. Beckman has argued that Hampton's defense of criminal disenfranchisement is "inconsistent with respect for the equal intrinsic worth of all" (2009,137). Lisa Hill (Hill 2010; Hill and Koch 2011) has highlighted the incompatibility between felon disenfranchisement and an attachment to human rights, or to rehabilitation. Whitt (2017) contended that Altman's justification of criminal disenfranchisement is self-defeating. The originality of our argument comes in three places. First, our performative contradiction critique is more systematic: because we envisage an entire normative approach (democratic expressivism), our critique can be extended to future arguments belonging to that approach. Second, our performative contradiction objection is supplemented with a vagueness objection. Third, we are the first to capitalize on these critiques to offer an alternative policy proposal concerning felons' voting rights.

${ }^{17}$ This is a slight terminological departure from Hintikka, and similar formulations such as Lewis' "pragmatic self-contradiction" (1969, 128-33), and Mackie's "pragmatic self-refutation" (Mackie 1964, 192). We are attracted to the expression "performative contradiction" because it highlights the idea of particular claims being advanced through particular acts or practices. This differs from a logical contradiction among semantically inconsistent propositional statements Declarative disenfranchisement is not logically contradictory.
} 
It would be a performative contradiction in the above sense to ground the act of civil disobedience on its expressing one's commitment to the legitimacy of the political order. Similarly, our critique charges expressive disenfranchisement with undermining the values that the act is intended to endorse.

How, then is expressive disenfranchisement a performative contradiction? Hampton grounds disenfranchisement on the value of equality. Democratic equality requires that citizens' interests are treated formally equally in the political process. As such, democratic regimes search for fair and neutral ways of adjudicating between different conceptions of the good. A commitment to democratic equality does not entail that different political views are equally valuable, but that citizens ought to have an equal stake in determining what constitute authoritative norms. For Hampton's account to succeed, disenfranchisement must suitably express the value of equality in response to serious crimes. But disenfranchisement is defined by the unequal treatment of certain criminals at one of the constitutive stages of the democratic process (voting in elections). Even accepting that some serious crimes constitute offenses to democratic values, it is contradictory to declare our commitment to political equality via a policy which holds that offenders are political unequals and that, consequently, their electoral standing can be discounted. ${ }^{18}$

To this, one might reply that democratic equality has limits, and that criminal disenfranchisement serves to express these limits. A version of this rejoinder can be found in Karl Popper's paradoxes of freedom, tolerance, and democracy. Freedom requires great restraint lest bullies use their freedom to "enslave the meek," tolerance requires the right not to tolerate "the onslaught of the intolerant," and majorities should be guided or restrained so as not to elect tyrants ([1945] 2012, 581-2).

This latter paradox has been examined by theorists of militant democracy. Loewenstein claimed that "if democracy believes in the superiority of its absolute values over the opportunistic platitudes of fascism (...), every possible effort must be made to rescue it, even at the risk and cost of violating fundamental principles" (Loewenstein 1937, 432; cf. Kirshner 2014). Similarly, one might argue that expressing an "unlimited" conception of equality in response to persons who undermine equality is self-defeating. But here we should note that militant democratic arguments are fundamentally instrumental. They hold that militant democratic

\footnotetext{
18 One response would be to say that the relevant form of equality is citizens being equally bound by the law, rather than their being political equals. But equal subjection to the law is not a distinctly democratic value. An autocratic state can also champion the rule of law. It is therefore unclear what is distinctly anti-democratic about a felons' disrespecting equal subjection to law. Further, grounding felon disenfranchisement in the expressive value of communicating 'being equally bound by law' seems to be a version of the discredited contractualist argument (see fn 3; Lippke 2001; Schall 2006; Beckman 2009). Finally, the value of being equally bound by the law is already expressed through punishment itself, raising a doubt about the expressive necessity of disenfranchisement.
}

measures come at a cost to democracy which is justified because of existential threats to it. ${ }^{19}$ Applied to expressivist arguments for criminal disenfranchisement, this implies that the risk to equality would need to be serious enough to justify the cost to democracy of treating prisoners as electoral unequals. That such a risk is serious enough is implausible. But even if we concede that an instrumental threat is serious enough to justify criminal disenfranchisement, this would not be justified on expressive grounds: such a policy of "militant disenfranchisement" would be instrumentally justified as a necessary measure for maintaining basic democratic institutions, with the explicit expressive cost of breaching equality.

Hampton might alternatively argue that temporary disenfranchisement is performatively consistent if we take it to express "that equality does not entail the recognition of the equal political standing of those who expressively violate equality." This rejoinder escapes the performative contradiction objection, but does so at a big cost. Thus interpreted, disenfranchisement might express the absence of a declarative commitment to equality in a range of specified cases, but it would not declare anything about a positive commitment to equality in other respects, which declarative disenfranchisement is meant to do. Similar to other cases of "illocutionary denegation" (Searle and Vanderveken 1985, 4), this interpretation denies the illocutionary force of the expressive act in question - in this case, the declaration of a commitment to democratic values - but cannot, by itself, declare that the demos is positively committed to equality. ${ }^{20}$

Sigler's trust-based account of disenfranchisement is also performatively contradictory. Here, the argument might seem more enigmatic, as breaches of trust commonly result in repercussions. For instance, if parents give their child pocket money, trusting them to spend it responsibly, and their child breaches this trust by buying cigarettes, a reasonable repercussion may well entail denying them further funds. This does not seem contradictory. Indeed, it seems a straightforward implication of the breach of trust: given the child's irresponsible behavior, parents no longer trust children with pocket money. This objection can be generalized. Persons depriving others of liberty are deprived of their liberty without contradiction. Persons treating others unequally in criminal ways are singled out from their peers for penal sanctions. ${ }^{21}$

As above, however, the performative contradiction is clear when we focus on the expressive nature of the

\footnotetext{
${ }^{19}$ See Loewenstein and $(1937,432)$, Kirshner $(2014,20)$.

${ }^{20}$ Illocutionary denegations "make it explicit that the speaker does not perform a certain illocutionary act" (Searle and Vanderveken 1985, 112). In Hampton's case, the illocutionary denegation would be 'We do not recognize the political equality of those who violate it.' This declaration cannot itself imply (nor express) that 'We recognize political equality among the members of the demos.'

${ }^{21}$ We do not claim that it is a logical contradiction to restrict an offender's rights or liberty (through imprisonment) when they criminally violate others' rights, liberty or claims to equality. Our argument instead insists that such sanctions cannot themselves express our positive commitment to these values.
} 
argument, i.e., when we take the withdrawal of trust to express the value of trust. Sigler's defense of disenfranchisement is not grounded on the idea that criminals cannot be trusted to use their vote responsibly. ${ }^{22}$ Disenfranchisement, in her account, serves to express the democratic community's commitment to the value of trust; in her words, it "affirms its normative identity" (2014, 1744). In the above example, further funds are straightforwardly denied to the child to mark disapprobation at their buying cigarettes. What one expresses, here, is "disapproval of the irresponsible behavior", not "trust" (either in her or in general). But the act of disenfranchising criminals marks out criminals as undeserving of civic trust - in other words, it communicates mistrust. And mistrust cannot coherently be the vehicle for expressing trust.

If Sigler were to construct her argument around the idea that criminal disenfranchisement serves to express the limits of or conditions to trust (rather than trust as such), she would fall into the same difficulties we saw with the 'illocutionary denegation' aimed at communicating the value of equality by specifying cases that ought to be treated unequally. While such a move would save her argument from performative contradiction, it would fail to vindicate disenfranchisement on declarative grounds: one cannot express a commitment to the positive value of trust merely by pointing to its limits. $^{23}$

Altman's and Bülow's accounts focus on the expressive value of disenfranchisement in the face of "important normative constraints" (Altman 2005, 269) - rights-violations - "that are fundamental to a free and democratic society" (Bülow 2016, 766). The performative contradiction here is most evident if we recognize the universal claim to voting in elections as a fundamental democratic right. Then, disenfranchisement would itself constitute a rights-violation and the argument would proceed on the same lines as forwarded against Hampton: how can a rights-violation express the validity of the value of respecting others' rights? Reading the universal claim to an equal vote as a human right is a common view, supported for instance by article 21 of the UN Declaration of Human Rights. It is indeed also the view endorsed by Altman and Bülow, who recognize that voting is a right rather than a privilege without recognizing the above contradiction. ${ }^{24}$

The performative contradiction objection shows that the attempts to ground criminal disenfranchisement as

\footnotetext{
${ }^{22}$ Though logically consistent, this would be a version of the 'republican' justification which she is critical of (see fn 3).

${ }^{23}$ Note also that our objection strictly applies to criminal disenfranchisement as a sufficient expression of trust, not to a wider practice that would include criminal disenfranchisement and pertain to be itself trust-expressive.

${ }^{24}$ Bülow construes the right to vote "as a fundamental right rather than a state privilege" $(2016,764)$. Altman's version is initially more cautious: "One can deny that the right to vote is a privilege rather than a right, while still holding that taking the right away from felons is a legitimate exercise of democratic self-determination" $(2005,265)$. But he clarifies that "the right to vote is not a privilege because all mentally competent, adult citizens of a state have a strong presumptive claim to the franchise" (ibid.).
}

a declaration of a commitment to equality, civic trust, or human rights (and, plausibly, on other democratic norms) are flawed. Disenfranchising citizens who are convicted of serious crimes cannot express commitment to these values without falling into a performative contradiction.

\section{THE VAGUENESS OBJECTION}

If sound, the performative contradiction objection is sufficient to discard the declarative and instructive rationales for criminal disenfranchisement, given that instructive views presuppose declarative noncontradiction. Hampton and Sigler however go further than Altman and Bülow. They not only care about the expressive value of criminal disenfranchisement for the demos but also argue that criminal disenfranchisement can serve to democratically instruct felons. Irrespective of one's position on the performative contradiction objection, we argue that the instructive rationale is vulnerable to a vagueness objection. This objection states that the predicate expressively instructive of democratic values is particularly indefinite in its application to the case of criminal disenfranchisement. Consequently, we cannot rely on it to provide a justification for criminal disenfranchisement. In raising this charge, we adopt a common understanding of vagueness, where $X$ is vague if one can point to borderline cases such that neither conceptual analysis nor empirical evaluation will be able to clearly settle whether those cases are instantiations of $X$.

We think that it is persistently unclear whether or how criminal disenfranchisement instantiates a process that is expressively instructive of democratic values. To wit, it is not clear what the instructive mechanisms whereby disenfranchisement teaches values like equality, trust, or about human rights are. Note that our objection is not that the predicate expressively instructive of democratic values is itself vague. The objection is that, because criminal disenfranchisement is among the borderline cases of the predicate under discussion, one cannot rely on the latter to justify the former.

Instructive expressivists hold that that some crimes constitute expressive violations of democratic values and that the felons who commit them can come to hold those same values through disenfranchisement. However, since the right to vote is the condition to participate in a practice (voting) by means of which democratic values are expressed, it is unclear how being excluded from the practice could help felons understand that their crimes are expressive wrongs or prompt a process that resensitizes them to those values. Put differently, it is not clear what the considerations are in virtue of which the predicate expressively instructive of democratic values applies to the case of criminal disenfranchisement.

Clarity matters here for distinctly expressive reasons. It is part of the "sincerity conditions" of instructing that the instructor intends to instruct the instructee. ${ }^{25}$ But

\footnotetext{
${ }^{25}$ We follow Searle's definition of the sincerity condition as "the psychological state expressed in the performance of the illocutionary act" ([1979] 2008, 5).
} 
neither intending to instruct nor asking someone to join an instructive process can be sincere if the instructor cannot clearly identify a plausible instructive mechanism. Absent this, the instruction is expressively defective. This failure is independent of instrumental considerations regarding the a posteriori efficiency of the instructive process.

As we see it, the instructive justification of expressive disenfranchisement could be clarified in two ways. First, felons could be indifferent to democratic values, in the sense that they do not recognize them qua values. This contention is plausible, but does not offer sufficient grounds for inferring that temporarily excluding them from an expressively valuable practice will make them recognize what they did not prior to their exclusion. If I do not recognize $V$ as a value and then I am told that $P$ is one of the best suited practices whereby commitment to $V$ is generally expressed, but that, given my expressive rejection of $V$ through action $A$, I am now barred from participating in $P$, it is not clear how such a bar will help me recognize the validity of $V$.

Second, felons could be assumed to recognize that democratic values are worth honoring, but may lack the motivation to incorporate these values in their practical deliberations. Here again, it is not clear how acquiring the practical motivation to act on democratic values would follow from being excluded from one of the basic practices (voting) that expresses those values. Whether we interpret the motivation to act on democratic values in terms of virtue (as Sigler) or, more generally, in terms of moral education (as Hampton), it remains persistently unclear how excluding someone from a practice (voting) that provides the experience of democratic values could at the same time help them acquire the moral motivation to honor those values. This would be like saying that depriving someone of an experience they have an interest in could, independently, contribute to them properly having that experience in the future. One does not follow from the other.

Neither of these two specifications explains how depriving serious offenders of their right to vote might instruct them about the normativity of democratic values. Furthermore, it remains unclear whether, even when it's time-restricted, disenfranchising offenders will not have the opposite effect to the expected one, i.e., teaching offenders that the demos does not care about them taking part in democratic practices. As Schall (2006) notes, "by placing a mark of infamy on convicts, disenfranchisement can lower criminals' self-esteem, place greater distance between them and the rest of society, and exacerbate the low regard in which others hold them" (92). Even in cases where it is time-bound, disenfranchisement might (just as well as it might not) teach offenders that they are second-class citizens and that, as such, their exclusion from and unequal treatment by the demos is justified. In other words, it remains unclear whether, and, if so, how temporary disenfranchisement is democratically instructing rather than alienating.

If, however, alienation were positively proven to be a stable effect of criminal disenfranchisement, the vagueness objection would disappear. This is because criminal disenfranchisement would be a clear case that does not instantiate the predicate expressively instructive of democratic values. But defenders of instruction could not coherently defend alienation. In denying that criminal disenfranchisement is instructively vague because it is alienating, one would escape the vagueness objection, but would also have to admit that criminal disenfranchisement is not democratically instructive.

Supporters of instructive disenfranchisement might alternatively argue that provisional disenfranchisement tells felons that other citizens regard them as political inferiors and thus highlights a dimension of political comparison felons did not properly appreciate before. To put it in Rousseau's terms, disenfranchisement could be said to awaken the felons' dormant amour-propre, which is a source of motivation we all have for wanting our special value recognized by others. ${ }^{26}$ This rejoinder is doubly problematic. First, since amour-propre will often result in inegalitarian preferences aimed at cultivating one's sense of superiority, it is unclear whether and why democratic expressivists should endorse it. Second, even if the democratic desirability of amourpropre could be substantiated, it remains particularly unclear whether and how amour-propre could outweigh other psychological states that might also be elicited by disenfranchisement, such as powerlessness, alienation, and feelings of political inferiority. ${ }^{27}$

The instructive rationale for expressive disenfranchisement might finally be defended by saying that whereas offenders would be temporarily deprived of their right to vote, they would nonetheless retain an adequate access to other political rights whose exercise would prepare them for a proper use of the right to vote. At a minimum, democratic states should foster the exercise of felons' right to access politically relevant information, to discuss this information with fellow inmates, and to form an opinion about politics and the electoral offer in place. In practicing an instructively oriented form of expressive disfranchisement, the state should, through its criminal justice system, encourage prisoners to make use of all these other rights in a way that prepare them for voting. This rejoinder is problematic on two counts. First, there seems to be an indelible tension between enabling (and, indeed, encouraging) prisoners to engage in practices that are arguably expressively thicker than voting - such as debating political information - and denying them the exercise of the expressively thinner right to vote.

Second, there are reasons to worry that simple temporary disenfranchisement policies already confuse both felons and electoral officials about when the former have the right to vote (Allen 2011; Drucker and Barreras 2005). It is plausible that the risk of confusion will be compounded by more complex policies that suspend voting rights while simultaneously stimulating the exercise of other political rights. If the risk of creating confusion is an expressive defect, this last

\footnotetext{
${ }^{26}$ See note XV to the Second Discourse and Emile.

${ }^{27}$ For an examination of these psychological aspects, see Lerman and Weaver (2014).
} 
rejoinder becomes hard to defend on expressivist grounds.

\section{DEMOCRATIC EXPRESSIVISM AND COMPULSORY CRIMINAL VOTING}

The above section detailed the reasons why democratic expressivism cannot justify criminal disenfranchisement. Nonetheless, we recognize the prima facie attractiveness of democratic expressivism, as well as the attractiveness of the argument that certain crimes are anathema to democratic values such that they require an expressive response. Not acting expressively in response to challenges to democratic values weakens a community's attachment to those values, since it could be taken to indicate that those values are not genuinely held. The question then arises: what is an adequate expressive response to those crimes that challenge democratic values? We propose that provisionally obliging such criminals to vote-at a minimum, for the length of one electoral cycle-offers such a response and contend that democratic expressivists should endorse it.

In this section, we first show how the compulsory vote is not in contradiction with a commitment to expressing democratic values. While clearing the way for compulsory voting as an expressive sanction, however, this first step does not yet provide positive reasons for obliging criminals to vote. Positively, then, we argue that the compulsory vote is an expressively unambiguous way for a democratic community to declare the validity of democratic values. Consequently, democratic expressivists have expressive reasons for endorsing compulsory criminal voting. Additionally, we argue that obliging offenders to vote is (more) likely to have a positive instructive impact on them, and clarify the logic behind mechanisms that might ensure instruction. Thus, those who expressively endorsed temporary criminal disenfranchisement on instructive grounds have further reasons to endorse our compulsory voting policy. After addressing some objections to our alternative view, we end by outlining the design of the compulsory criminal voting policy.

Unlike expressive criminal disenfranchisement, expressive compulsory criminal voting is not performatively contradictory. Recall that the performative contradiction of expressive disenfranchisement turned on the contradiction of the act (disenfranchisement) with the values that it sought to express (we examined equality, civic trust, and human rights). With regard to civic trust, the absence of a performative contradiction is straightforward: while denying certain felons the vote would mark a breach in trust in ways that fail to express the value of trust positively, obliging felons to vote does not raise the same concern. The absence of a performative contradiction grounded on the value of human rights is similarly uncomplicated. While forcing felons to vote one way or another may violate civic human rights, our proposal, which sanctions nonparticipation, while coercive, is no violation of fundamental rights.

Equality is more difficult, although here too we argue that the compulsory vote does not introduce an inequality that is in conflict with democratic values. That there is an element of inequality introduced by obliging (certain) felons to vote is not in question; while general compulsory voting has been argued to improve equality between citizens (Lacroix 2007; Lardy 2004; Lijphart 1997), compulsory criminal voting would result in two unequal categories of enfranchised citizens: those with the power but without the obligation to vote, and those with the power to vote who are obliged. From the standpoint of democratic equality, though, what matters is equal electoral power, which is kept intact by compulsory criminal voting. Offenders who are obliged to vote and those who are not have a formally equal voting share. Furthermore, the inequality pertaining to compulsory criminal voting would not be imposed arbitrarily: only convicted criminals who commit offenses in violation of foundational democratic norms would be temporarily obliged to vote. While the disenfranchisement of criminals is non-arbitrary in the same way, disenfranchisement creates an additional inequality that is in direct contradiction with the democratic commitment to treating different, and potentially conflicting, views equally. Doing so breaks with the expressive commitment to communicating the value of democratic equality.

Perhaps though the compulsory vote treats unequally other citizens, who merely have the power but not the obligation to vote. Consider the following stylized example: in Compulsovo, a state of 200 citizens, electoral turnout is ordinarily about $60 \%$. When electing 20 parliamentarians following proportional representation rules, two parties run: the Reds and the Blues. Polling shows that $55 \%$ of citizens would vote Red and $45 \%$ would vote Blue. Electoral turnout is equally distributed among partisans of Red and Blue, such that Blue ought to expect 54 votes/9 seats and Red 66 votes/ 11 seats. However, Compulsovo obliges its prisoners to vote. Of the 200, a huge 30 are incarcerated. Further, these 30 are not representative: $80 \%$ of them would ordinarily vote Blue and only $20 \%$ Red. Given that these 30 citizens are obliged to vote, and the remaining 170 are not, the election results are as follows: Blue wins 70 votes $/ 11$ seats $(170 \times 0.6 \times 0.45+30 \times 0.8)$, and Red wins 62 votes $/ 9$ seats $(170 \times 0.6 \times 0.55+30 \times 0.2)$. The compulsory voting policy thus has the effect of inversing the electoral outcome relative to merely enfranchising felons. This effect (and any similar nonstylized realworld effects, arguably even where the outcome of the election shifts less dramatically) seems in conflict with democratic equality.

This objection can be read in two different ways: either the putative inequality is instrumentally problematic since it leads to undesirable outcomes or it is intrinsically incompatible with democratic equality. The instrumentalist objection can be countered in various ways. First, it rests on unproven and implausible empirical assumptions about felons (Reiman 2005; Sigler 2014). ${ }^{28}$ Offenders' political identity is not defined by

\footnotetext{
${ }^{28}$ As such, the objection belongs to the class of 'republican' arguments for criminal disenfranchisement that are explicitly rejected by Sigler (2014, 1731; see also fn 3).
} 
their so-called immoral character (López-Guerra 2014), so even on the negligible chance that obliging certain criminals to vote would impact an electoral outcome, this would not thereby subvert it but would improve the legitimacy of the outcome relative to felon disenfranchisement. A subtler version of this argument might postulate that obliging some felons to vote may render the vote unfairly partisan because involuntary voters may be more likely to vote for fringe parties, either by casting votes randomly, or as an act of protest (see Birch 2008, 122 for discussion). However, evidence suggests that this hypothesis is false (ibid., 122-3, 125-6), and, in any case, any proven similar effect would be negligible in the context of our compulsory criminal voting proposal, where only a small fraction of the total population would be obliged to vote. Thus, the compulsory vote does not introduce an instrumentally problematic inequality.

If, in contrast, the putative inequality is intrinsically grounded on democratic commitments, we hold that the response equivocates on the meaning of democratic equality. A relevant inequality would be weighting certain votes more strongly than others; this would break with the core democratic principle of "one person, one vote." The objection under consideration turns, rather, on groups being treated unequally. This is not justified on democratic grounds, as democracy recognizes no legitimate pre-procedural group interests. Furthermore, the 'solution' to those posited to be harmed by this inequality would be in their own hands, since non-incarcerated citizens preferring Red retain the right to vote. ${ }^{29}$ In sum, there is no charge that sticks against the declarative value of the compulsory vote from performative contradiction with democratic values.

Obliging those criminals who have expressively rejected democratic values to vote would be an adequate expression of a democratic community's commitment to the values of, inter alia, civic trust, human rights and equality. We agree with Sigler that "the right to vote is the relevant currency to mark the breach of trust because, unlike criminal punishment, voting is linked directly to citizenship and the rights and responsibilities of that office" (1737-8). The compulsory vote uses this currency without debasing it. ${ }^{30}$ The human right to participation and representation is, by compulsory criminal voting, not traded off as something that is granted contingently and must be 'deserved'. Felons who are obliged to vote have, through their crimes, broken with their duties as democratic citizens. Obliging them to go through the motions of exercising

\footnotetext{
${ }^{29}$ This is something we can assume they would do in higher numbers if they felt their interests were otherwise threatened by compulsory criminal voting (Saunders 2010, 150).

${ }^{30}$ Another possible objection focuses on a supposed 'right not to vote' that may be violated by compulsory voting (Lever 2010; Brennan in Brennan and Hill 2014, 3-107; Saunders 2017, 2018). Whether there is such a right is disputed (Lardy 2004; Lacroix 2007; Hill 2010; Hill in Brennan and Hill 2014, 154-73). Prominent arguments for it, however, are cast against general compulsory voting (Lever 2010; Saunders 2017, 2018) and have little purchase on our limited compulsory criminal voting policy (Saunders 2010).
}

(one of their) democratic duties adequately expresses a commitment to both the inviolable right and the violated duty. To use Hampton's words, where these criminals' actions have expressed "I am up here, and you are down there; so I can use you for my purposes" (39), the compulsory vote expresses the contrary, namely, that we are all in this together. Compulsory criminal voting thus serves as a declarative expression of the democratic community's commitment to these values.

Though performatively consistent and declaratively adequate, our proposal might be argued to be vague in a different way, and thus nevertheless expressively defective. Dan Kahan argues that while imprisonment is expressively straightforward in that it ordinarily causes inmates to suffer, alternative sanctions express moral approbation unclearly $(1996,593)$. It may seem that Kahan's case for the expressive superiority of imprisonment over alternative sanctions would weigh against our proposal. However, our defense of compulsory voting does not depend on making offenders suffer. We separate the desirable expression of democratic values from the putative desiderata of penal sanctions more generally. The compulsory vote is expressively valuable in that it expresses the political dimension of certain crimes. Even on a retributive penal theory, it is unclear how the concern would count against our proposal. We are not arguing, after all, that the compulsory vote should replace punishment, but that it should complement it (much like criminal disenfranchisement is often conceived in regulatory rather than punitive terms [Altman 2005, 265; Sigler 2014, 1728]).

Compulsory criminal voting is not only declaratively adequate but also promises to be instructively clear. Unlike disenfranchisement, our policy proposal relies on plausible instructive mechanisms. In what follows, we point to two such mechanisms-democratic habituation and democratic emulation - that specify our instructive defense of compulsory criminal voting.

Democratic habituation is a gradual process whereby a person gains the skills and routines typically required for following rules of democratic behavior and experiencing democratic values. ${ }^{31}$ There is no need to endorse a demanding ideal of democracy to recognize that there are some habits-for instance, listening and responding to others during a political conversation, seeking out political information, taking part in collectively significant events, or contacting government officials-which are necessary for the functioning of a democratic polity and reasonable to expect from its citizens.

Given its centrality to democratic practice, we think that voting provides a felicitous venue for democratic habituation. In particular, compulsory voting can prompt or support democratic habits. Here, we draw on Ben Saunders' (2010) proposal for obliging everyone - most often, young people and naturalized immigrants - to vote for the first elections where they have the right to do so. Saunders' rationale for a one-off initial compulsory

\footnotetext{
${ }^{31}$ On democratic habits, see Dewey (1937).
} 
vote is "to ensure that all potential voters are exposed to politics and know what it takes to vote" (149). Following Saunders, obliging everyone to vote at least once offers an equal opportunity for "tasting democracy," such that even if people subsequently choose to abstain from voting, they "have had a taste of their democratic rights" (150). The contention is that if we "get people to vote for the first time, (...) they may well form a habit and continue to do so" (150). Saunders' contention sounds plausible: like other habits where some coercion is initially needed-say, learning hygiene routines or acquiring basic intellectual skills-some coercion might initially be useful to engage or keep engaging in democratically valuable practices.

For Saunders' argument to hold, it suffices to show that obliging people to vote once is habit-forming. There is evidence that a single act of voting makes it more likely that people will continue to vote in future elections (Gerber, Greene, and Schachar 2003; Meredith 2009). Moreover, some of the most plausible hypotheses for explaining why voting is habit-forming are expressively pertinent. For instance, Gerber, Greene and Schachar suggest that "civic participation subtly alters the way that citizens look at themselves," and that "the more one votes, the more one comes to regard going to the polls as 'what people like me do on election day"” (2003, 548). Similarly, Fujiwara, Meng, and Vogl (2016) argue that the expressive value people come to associate with the act of voting is "the most likely mechanism" underlying its habit-forming force.

In light of this, our argument that compulsory criminal voting might work via habituation can be summarized as follows: given that a single act of voting is habit-forming and that compulsory voting typically increases the probability of acts of voting, a policy of provisional compulsory voting will have habit-forming effects. Compulsory voting will be especially suitable for young offenders who vote for the first time and for offenders who are de facto disenfranchised. Since most felonies are committed by people around the age where they can vote for the first time ${ }^{32}$ and because many felons are already subject to de facto disenfranchisement (Burch 2011; Uggen and Manza 2004), many felons will be suitable for habituation via compulsory voting.

Compulsory voting might also be relevant for offenders who have been electorally active prior to their imprisonment. This is because mere contact with the criminal justice system-from police encounters to incarceration-has been shown to negatively affect one's civic self-perception and probability to vote (Lerman and Weaver 2014). More specifically, Uggen, Manza, and Behrens (2004) found that many offenders thought being labeled a felon meant that they did not count as political equals anymore, which in turn might have led them to voting abstention. If this is true, then, by expressively signaling that all members of the polity

\footnotetext{
32 See Rocque, Posick, and Hoyle (2016, 1-8) for a discussion of the age-crime relationship.
}

are political equals, a provisional compulsory voting policy can push back on these negative effects and contribute to maintaining (instead of creating) democratic habits. ${ }^{33}$

A second mechanism whereby compulsory criminal voting could fulfill its instructive function is democratic emulation. We construe emulation as a learning process aimed at embodying another person's behavior or attitudes that one finds valuable in some respect. Democratic emulation is the more specific process where the value underlying the emulated behavior or attitudes is democratic or democratically relevant. Compulsory criminal voting could promote democratic emulation in at least two ways. First, it could provide the opportunity for emulation among felons. Given its likely positive effects on turnout, compulsory criminal voting would, at a minimum, reveal that there are at least some felons who can successfully engage in democratic politics - by voting, but also by competently discussing the electoral offer, seeking political information, or petitioning parliamentary representatives. If properly publicized, examples of such felons could serve as rolemodels for other, democratically unpersuaded or indifferent offenders. It would show offenders that felony is not fate, and that a criminal conviction does not automatically drive out civic claims or aspirations. Indeed, some leadership initiatives that pursue criminal justice reforms, where ex-felons serve as role-models currently convicted felons can emulate, are premised on an emulating logic. ${ }^{34}$

Second, compulsory criminal voting might prompt felons to emulate members of the demos who support the policy. In obliging the relevant felons to vote, the members of the demos would show that they are willing to allocate significant resources to bringing democratic values to bear on the practical deliberations of those who have trampled them. Compared to the less expensive options of criminal disenfranchisement or mere (re-)enfranchisement, compulsory criminal voting can better signal that democracy is worth the cost even when the prospects of it being appreciated remain $\operatorname{dim} .{ }^{35}$ If the cost of a public policy expresses its public importance, compulsory criminal voting is comparatively well placed for expressing the importance the demos gives to felons being persuaded by the cogency of democratic values. In

\footnotetext{
${ }^{33}$ Drawing on Elliott's (2017) pre-commitment argument in favor of mandatory voting, the idea of maintaining the democratic habits of factually non-disenfranchised felons could be more clearly construed as a strategy whereby the state expressively pre-commits to the preservation of democratic habits.

${ }^{34}$ For a narrative of such an account, see: https://www.forbes.com/ sites/laurensonnenberg/2017/08/26/a-former-felon-leads-the-way-incriminal-justice-reform/\#31e9ac777bb9 (accessed August 2018).

${ }^{35}$ One could argue that establishing a legal obligation to vote signals the state's commitment to make voting easily accessible. Birch (2008, 7) argues that, once compulsory voting is in place, a generally inefficient access to voting facilities would increase the state's ex post enforcement costs. If this is right, obliging offenders to vote is a more adequate policy for expressing the state's commitment to have felons experience democratic values via voting than merely encouraging them to vote, as Ewald $(2003,35)$ proposes.
} 
so doing, the demos provides felons with a clear and steady model of democratic commitment.

The expressive adequacy of compulsory voting depends on matters of institutional design. On our proposal, compulsory voting does not mean that the state would physically force felons to vote or pressure them to cast a valid ballot. Such acts would count as electoral fraud, with someone else taking or manipulating the offender's electoral choice. As is standard, compulsory voting here only means compulsory electoral turnout, i.e., a voting system that establishes a legal obligation which is discharged by simply attending a polling station. ${ }^{36}$ Defining compulsory voting as mandatory turnout means that felons would be allowed to spoil their vote - for instance, by refusing to mark a choice on their ballot or by marking the ballot in a way that nonviolently transgresses the rules of the voting system. $^{37}$

Moreover, it is expressively desirable that felons be given the option of marking a positive abstention. This could be done formally by introducing a "no candidate" option on the ballot. Because it gives felons a forum to actively communicate their dissatisfaction, designing the ballot in this manner is expressively superior to the abstention imposed by criminal disenfranchisement and, given the live possibility of de facto disenfranchisement, to the abstention allowed by re-enfranchisement policies.

Compulsory criminal voting, in short, means presenting the relevant felons with a choice between attending the polling station and incurring a legal sanction for not voting. The form of that sanction should be determined via democratic law-making. Even so, there are at least three expressive constraints that democratic legislators ought to consider. First, legislators should avoid introducing expressively questionable sanctions - for instance, harsh additional imprisonment terms or naming-and-shaming sanctions that would engender or compound antidemocratic stigmatization. Second, legislators should allow for a regime of defenses that would eliminate or reduce the severity of sanctions under appropriate circumstances. These defenses should include justifications for felons who fail to vote because of unsafe, inaccessible, or otherwise inadequate voting facilities, as well as excuses premised on illness or disability. ${ }^{38}$ Third, in states with general compulsory voting, sanctions imposed for failing to comply with compulsory criminal voting should be clearly distinguishable from sanctions attached to general nonvoting. This could be done cumulatively, by

\footnotetext{
${ }^{36}$ This requires that polling stations be reasonably accessible to felons both in and outside prisons. We imagine the effect of our compulsory criminal voting proposal to generally track imprisonment in terms of length; in any case, it ought to be limited to, maximally, the duration of the - custodial or non-custodial-criminal sentence and, minimally, to one electoral cycle.

37 On this point, we follow Hill (Brennan and Hill 2014, 144-5).

${ }^{38}$ For a recent discussion of excuses in relation to general compulsory voting, see Elliott $(2017,658)$. The combination of such expressive constraints with the option of blank or spoiled ballots suffices, in our view, to assuage worries that our policy interferes with felons' characters and violates state neutrality (see Saunders 2010, 150-1).
}

adding the sanctions for felons not voting to those they would already incur.

These expressive constraints leave a number of potentially adequate sanctions open to the choice of democratic representatives. Drawing on examples of sanctions enforced in compulsory voting systems, ${ }^{39}$ legislators might consider a system of symbolic reprimands as responses to less severe violations of democratic values or, when it comes to more serious antidemocratic wrongs, choose heavier sanctions like day-fines that could be directed toward democratically relevant organizations or activities. ${ }^{40}$

Finally, compulsory criminal voting should be preceded by a process of democratic instruction that engages with the relevant felons through a series of suitably designed civic education programs. This last instructive feature draws on a number of alternative sanctions currently practiced in countries like France, where it takes the form a civic internship (stage de citoyenneté). These alternative sanctions mainly target young offenders, but they can also apply to adults. Typically, a stage de citoyenneté is part of a conditional offer where the offender has to choose between the civic internship and a dissuasively long term of imprisonment. ${ }^{41} \mathrm{~A}$ stage is meant as a reparative sanction. It is used for offenses that have a civic or political component (such as vandalism or aggressing a police officer) and aims to remind offenders about the values of tolerance and respect for human dignity. A stage can be organized within correctional facilities or in more symbolically relevant venues, such as Holocaust museums or theaters. A stage is usually organized as a mediated dialogue between offenders and a criminal justice official-for instance, a judge-and is oriented toward calling attention to the value of civic interaction and peacefully articulated disagreements. A stage can also include less conventional activities, such as theater performances or watching and discussing relevant cinematographic material-for example, documentaries about discrimination or domestic violence.

Drawing on the example above, our suggestion is that offenders who would be disenfranchised on the expressive disfranchisement proposal should instead be obliged to vote and to follow programs similar to the stage. The justification of such civically minded programs depends on their specific content and pedagogical style, and, in particular, on their readiness to make room for critical disagreement and contestation. Conditional on these specifics being properly designed and enforced, we think that compulsory voting is a better tool for instructing the relevant felons about the significance of democratic values.

\footnotetext{
${ }^{39}$ See Birch (2008, 9-10).

${ }^{40}$ Another advantage of day-fines is that they are adjusted to avoid overburdening economically disadvantaged felons.

${ }^{41}$ On our proposal, imprisonment would be replaced with expressively apt sanctions like the ones suggested above, but we do not exclude resorting to proportional prison terms as a last-resort option.
} 


\section{CONCLUSION}

In this article, we argued that justifying criminal disenfranchisement on democratic expressivist grounds should be rejected because it is performatively contradictory and instructively vague. These two defects are particularly damaging to any justification grounded in democratic expressivism. We have also argued that temporarily obliging serious offenders to vote is better for conveying the attachment of the demos to its values, and for bringing the offender back into the democratic fold. Furthermore, our proposal is, we contended, immune to the abovementioned defects.

We are aware of the practical obstacles that our proposal would encounter. These obstacles include, for instance, securing the resources needed for a successful design and implementation of compulsory criminal voting or facing the resistance that the proposal might elicit from some groups within the demos. Speaking to the question of scarce resources, the costs of our proposal could be reduced with support coming from voluntary civic organizations and other volunteer citizens. There are no compelling reasons to think that the proposal will fail to garner the civic backing that would keep its costs reasonable. Concerning the potential resistance to the proposal, we admit that its endorsement remains conditional on the creativity and cogency of the campaigning that will go into it, the quality of the public deliberative processes whereby its particulars will be decided, and the strategies pursued in promoting it. Similar to many of the past electoral reforms achieved by democratic polities, the felicity conditions for the reform we propose will not be fastened instantly, but gradually, and will not be given, but made.

\section{REFERENCES}

Allen, Jessie. 2011. "Documentary Disenfranchisement." Tulane Law Review 86 (2): 389-464.

Altman, Andrew. 2005. "Democratic Self-Determination and the Disenfranchisement of Felons." Journal of Applied Philosophy 22 (3): 263-73.

Anderson, Elizabeth S. 2009. "Democracy: Instrumental versus Noninstrumental Value." In Contemporary Debates in Political Philosophy, eds. Thomas Christiano and John Christman. Malden, Massachusetts: Wiley-Blackwell, 213-27.

Anderson, Elizabeth S., and Richard H. Pildes. 2000. "Expressive Theories of Law: A General Restatement." University of Pennsylvania Law Review 148: 1503-75.

Beckman, Ludvig. 2009. The Frontiers of Democracy: The Right to Vote and its Limits. New York: Palgrave Macmillan.

Bennett, Christopher. 2016. "Penal Disenfranchisement." Criminal Law and Philosophy 10 (3): 411-25.

Birch, Sarah. 2008. Full Participation: A Comparative Study of Compulsory Voting. Manchester: Manchester University Press.

Blais, André, Louis Massicotte, and Antoine Yoshinaka. 2004. Establishing the Rules of the Game. Toronto: University of Toronto Press.

Brennan, Geoffrey, and Loren E. Lomasky. 1993. Democracy and Decision: The Pure Theory of Electoral Politics. New York, NY: Cambridge University Press.

Brennan, Jason, and Lisa Hill. 2014. Compulsory Voting: For and Against. New York, NY: Cambridge University Press.

Bülow, William. 2016. "Felon Disenfranchisement and the Argument from Democratic Self-Determination." Philosophia 44 (3): 759-74.
Burch, Traci. 2011. "Turnout and Party Registration Among Criminal Offenders in the 2008 General Election." Law \& Society Review 45: 699-730.

Carr, David. 1991. "Education and Values." British Journal of Educational Studies 39 (3): 244-59.

Chapman, Emilee. 2016. "Voting Matters: A Critical Examination and Defense of Democracy's central Practice." Ph.D. Dissertation. Princeton University.

Cholbi, Michael J. 2002. "A Felon's Right to Vote." Law and Philosophy 21 (4/5): 543-65.

Clegg, Roger. 2001. "Who Should Vote." Texas Review of Law \& Politics 6: 160-78.

Dewey, John. 1937. "Democracy and Educational Administration." School and Society 45: 457-67.

Drucker, Ernest, and Ricardo Barreras. 2005. "Study of Voting Behavior and Felony Disenfranchisement Among Individuals in the Criminal Justice System in New York, Connecticut, and Ohio.” The Sentencing Project. Available at: https:/www.reentry.net/ny/ search/item.110853.

Elliott, Kevin J. 2017. “Aid for Our Purposes: Mandatory Voting as Precommitment and Nudge." The Journal of Politics 79 (2): 656-69.

Ewald, Alec. 2002. "Civil Death: The Ideological Paradox of Criminal Disenfranchisement Law in the United States." Wisconsin Law Review 5: 1045-147.

Ewald, Alec. 2003. "Punishing at the Polls: The Case against Disenfranchising Citizens with Felony Convictions." Demos. Available at: https://www.prisonpolicy.org/scans/demos/punishing_at_the_polls. pdf.

Fujiwara, Thomas, Kyle Meng, and Tom Vogl. 2016. "Habit Formation in Voting: Evidence from Rainy Elections." American Economic Journal: Applied Economics 8 (4): 160-88.

Gerber, Alan S., Donald P. Green, and Ron Shachar. 2003. "Voting May Be Habit-forming: Evidence from a Randomized Field experiment." American Journal of Political Science 47 (3): 540-50.

Gutmann, Amy, and Dennis Thompson. 2004. Why Deliberative Democracy? Princeton: Princeton University Press.

Hampton, Jean. 1998. "Punishment, Feminism, and Political Identity: A Case Study in the Expressive Meaning of Law." Canadian Journal of Law and Jurisprudence 11 (1): 23-45.

Hill, Lisa. 2010. "On the Justifiability of Compulsory Voting: A Reply to Lever." British Journal of Political Science 40 (4): 917-23.

Hill, Lisa, and Cornelia Koch. 2011. "The Voting Rights of Incarcerated Australian Citizens." Australian Journal of Political Science 46 (2): 213-28.

Hintikka, Jakko. 1962. "Cogito, Ergo Sum: Inference or Performance?" Philosophical Review 71 (1): 3-32.

Kahan, Dan. 1996. "What Do Alternative Sanctions Mean?" University of Chicago Law Review 63 (2): 591-653.

Kirshner, Alexander S. 2014. A Theory of Militant Democracy: The Ethics of Combatting Political Extremism. New Haven, Connecticut: Yale University Press.

Lardy, Heather. 2004. "Is There a Right Not to Vote?" Oxford Journal of Legal Studies 24 (2): 303-21.

Lacroix, Justine. 2007. "A Liberal Defence of Compulsory Voting." Politics 27 (3): 190-5.

Lerman, Amy E., and Vesla M. Weaver. 2014. Arresting Citizenship: The Democratic Consequences of American Crime Control. Chicago: University of Chicago Press.

Lever, Annabelle. 2010."Compulsory Voting: A Critical Perspective." British Journal of Political Science 40: 897-915.

Lewis, Clarence I. 1969. Values and Imperatives. Stanford, California: Stanford University Press.

Lijphart, Arend. 1997. "Unequal Participation: Democracy's Unresolved Dilemma Presidential Address, American Political Science Association." American Political Science Review 91 (1): 1-14.

Lippke, Richard. 2001. "The Disenfranchisement of Felons." Law and Philosophy 20 (6): 553-80.

Loewenstein, Karl. 1937. "Militant Democracy and Fundamental Rights, I." American Political Science Review 31 (3): 417-32.

López-Guerra, Claudio. 2014. Democracy and Disenfranchisement: The Morality of Electoral Exclusions. Oxford: Oxford University Press.

Mackie, John L. 1964. "Self-Refutation-A Formal Analysis." The Philosophical Quarterly 14 (56): 193-203. 
Manfredi, Christopher, P. 1998. "Judicial Review and Criminal Disenfranchisement in the United States and Canada." Review of Politics 60 (2): 277-306.

Meredith, Marc. 2009. "Persistence in Political Participation." Quarterly Journal of Political Science 4 (3): 187-209.

Peters, Richard S. (1977) 2005. Education and the Education of Teachers. London: Routledge.

Pettit, Philip, and Geoffrey Brannan. 1986. "Restrictive Consequentialism." Australasian Journal of Philosophy 64 (4): 438-55.

Popper, Karl. (1945) 2012. The Open Society and its Enemies. Abingdon: Routledge.

Ramsay, Peter. 2013. "Voters Should Not Be in Prison! the Rights of Prisoners in a Democracy." Critical Review of International Social and Political Philosophy 16 (3): 421-38.

Reiman, Jeffrey. 2005. "Liberal and Republican Arguments against the Disenfranchisement of Felons." Criminal Justice Ethics 24 (1): 3-18.

Rocque, Michael, Chad Posick, and Justin Hoyle. 2016. "Age and Crime." In Encyclopedia of Crime and Punishment, eds. Wesley Jennings, George E. Higgins, Mildred M. Maldonado-Molina, and David N. Khey. Chichester, U.K.: John Wiley \& Sons, Inc., 1-8.

Saunders, Ben. 2010. "Tasting Democracy: A Targeted Approach to Compulsory Voting." Public Policy Research 17 (3): 147-51.

Saunders, Ben. 2017. "A Defence of the Right Not to Vote.” In Ethics in Politics: The Rights and Obligations of Individual Political Agents, eds. Emily M. Crookston, David Killoren, and Jonathan Trerise. New York: Routledge, 254-68.

Saunders, Ben. 2018. "A Further Defence of the Right Not to Vote." Res Publica 24 (1): 93-108.
Schall, Jason. 2006. "The Consistency of Felon Disenfranchisement with Citizenship Theory." Harvard Blackletter Law Journal 22: 53-93.

Searle, John. (1979) 2008. Expression and Meaning. Cambridge: Cambridge University Press.

Searle, John R., and Daniel Vanderveken. 1985. "Speech Acts and Illocutionary Logic." In Logic, Thought and Action. Dordrecht: Springer, 109-32.

Sigler, Mary. 2014. "Defensible Disenfranchisement." Iowa Law Review 99: 1725-44.

Thompson, Dennis. 2004. Just Elections: Creating a Fair Electoral Process in the United States: Chicago: University of Chicago Press.

Tripkovic, Milena. 2016. "The Modern Cives Sine Suffragio: Dimensions of Criminal Disenfranchisement in Europe." The Howard Journal of Crime and Justice 1 (2): 4-24.

Uggen, Christopher, and Jeff Manza. 2004. "Voting and Subsequent Crime and Arrest: Evidence from a Community Sample." Columbia Human Rights Law Review 36: 193-215.

Uggen, Christopher, Jeff Manza, and Angela Behrens. 2004. “'Less Than the Average Citizen': Stigma, Role Transition and the Civic Reintegration of Convicted Felons." In After Crime and Punishment: Pathways to Offender Reintegration, eds. Shadd Maruna and Russell Immarigeon. Ann Arbor, Michigan: Willan, 261-92.

Whitt, Matt S. 2017. "Felon Disenfranchisement and Democratic Legitimacy." Social Theory and Practice 43 (2): 283-311.

Winkler, Adam. 1993. "Expressive Voting." NYU Law Review 68: 330-88.

Wringe, William. 2016. An Expressive Theory of Punishment. New York: Palgrave MacMillan. 